\title{
SMALL-SCALE HYDROELECTRIC POWER DEMONSTRATION PROJECT :-
}

\section{INEXPENSIVE CROSS-FLOW HYDROPOWER TURBINE AT ARBUCKLE MOUNTAIN HYDROELECTRIC PROJECT}

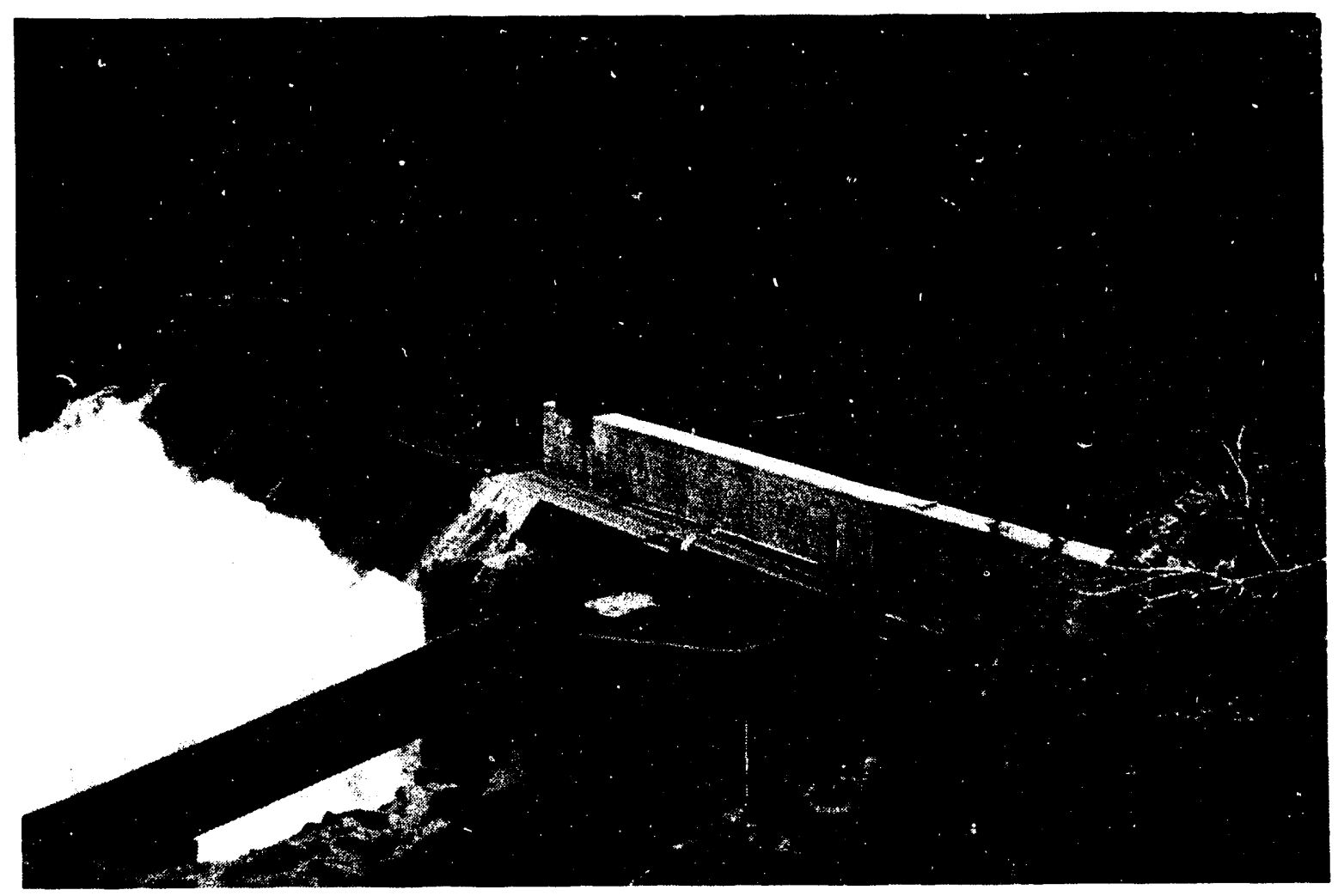

FINAL OPERATION AND MAINTENANCE REPORT 
Printed in the United States of America

Available from

National Technical Information Service

U.S. Department of Commerce

5285 Port Royal Road

Springfield, VA 22161

NTIS Price Codes: Printed Copy A02

Microfiche A01

\section{DISCLAIMER}

This book was prepared as an account of work sponsored by an agency of the United States Government. Neither the United States Government nor any agency thereof, nor any of their employees, makes any warranty, express or implied, or assumes any legal liability or responsibility for the accuracy, completeness, or usefulness of any information, apparatus, product or process disclosed, or represents that its use would not infringe privately owned rights. References herein to any specific commercial product, process, or service by trade name, trademark, manufacturer, or otherwise. does not necessarily constitute or imply its endorsement, recommendation, or favoring by the United States Government or any agency thereof. The views and opinions of authors expressed herein do not necessarily state or reflect those of the United States Government or any agency thereof. 


\section{SMALL-SCALE HYDROELECTRIC POWER DEMONSTRATION PROJECT}

\section{INEXPENSIVE CROSS-FLOW HYDROPOWER TURBINE AT ARBUCKLE MOUNTAIN HYDROELECTRIC PROJECT}

FINAL OPERATION AND MAINTENANCE REPORT

By

OTT Engineering, Inc.

Bellevue, Washington

July, 1991

Prepared for the

U.S. Department of Energy

Cooperative Agreement No. DE-FC07-84ID12481 


\section{TABLE OF CONTENTS}

Page

INTRODUCTION

PROJECT DESCRIPTION

KEY PROJECT DATA

MAJOR REPAIRS

ANNUAL OPERATING EXPENSES

\section{LIST OF PHOTOGRAPHS}

Photograph

1

2

3

4

TURBINE - GENERATOR

Page

10

GENERATOR - SWITCHGEAR

10

DIVERSION AT HIGH FLOWS

11

POWERHOUSE AT HIGH FLOWS

11

\section{LIST OF TABLES}

$\underline{\text { Table }}$

OPERATION AND MAINTENANCE COST

Page

2

STREAM FLOW AND PRODUCTION

12

14

\section{니ST OF FIGURES}

Figure

Page

FACILITY LOCATION

16

2

GENERAL PROJECT CROSS SECTION

TURBINE - DRAFT TUBE, SECTION

TURBINE DIMENSIONS

TURBINE EFFICIENCY 


\section{INEXPENSIVE CROSS-FLOW HYDROPOWER TURBINE AT ARBUCKLE MOUNTAIN HYDROELECTRIC PROJECT FINAL OPERATION AND MAINTENANCE REPORT}

\section{INTRODUCTION}

This report documents the first three and half years of operation and maintenance on the Arbuckle Mountain Hydroelectric Project. Located on a flashy mountain stream in northern California, the project was designed, built and tested through a Cooperative Agreement between the U.S. Department of Energy (DOE) and OTT Engineering, Inc. (OTT) of Redding, California. The purpose of the Agreement is to build and intensively test an inexpensive American-made cross-flow turbine and to provide information to the DOE on the cost, efficiency, operation, and maintenance of the unit. It requires that OTT document for DOE a summary of the complete operating statistics, operation and maintenance cost, and revenues from power sales for a two-year operating period.

A complete report covering the environmental, technical criteria, design, construction, and other related aspects of the total project was published by DOE as the "Final Construction and Cost Report" in July 1988. Extensive efficiency testing of the turbine was completed in 1989 and the "Field Test Report" was published by DOE in November 1989. Since these reports discuss the project elements in detail, they will only be mentioned here. However, several unique events occurred between the initial start-up (December 1986) and the beginning of the 1989 generation season (October 1988) that delayed the first year's full operation and provided unique information for a demonstration project of this type. Accordingly, this report will discuss certain major problems experienced with the design, operation and maintenance, and energy production, as well as the operation and maintenance costs and value of the power produced for the first three and half years of operation.

For reasons that are given in the body of this report, it is evident that due to numerous problems there has been no significant period of time to date that would be representative 
of operating data reflecting the normal production that can be expected from this project. Principle among these circumstances are the following:

1. Once "on-line" the electrical system, the 1910 vintage generator, and the turbine inlet valve had to be completely rebuilt.

2. Drought of 1987.

3. An operator error flooded the powerhouse in November 1987.

4. Drought of 1988.

5. Failure of the air line from the powerhouse to the fish screens at the diversion.

6. Drought of 1989.

7. Drought of 1990.

Many of these matters were discussed in detail in the "Final Construction and Cost Report" and the "Field Test Report" and will be covered only briefly in this report.

\section{PROJECT DESCRIPTION}

The project is located on the Middle Fork of Cottonwood Creek, five miles north of Platina in Shasta County, California (Figure 1). The site provided an excellent opportunity to test operation and monitoring of a remote run-of-river installation that is typical of small hydroelectric projects. It was totally undeveloped and required extensive roads, bridges, and five miles of powerline to connect to the local power utility. New site facilities included a diversion and intake structure, steel penstock, powerhouse, and switchyard. Figure 2 shows the general project cross section. The turbine section and dimensions are shown in Figures 3 and 4 , respectively.

The turbine was designed for a maximum of $400 \mathrm{~kW}$ with an average annual project output of $904,000 \mathrm{~kW}$ hours. After intensive testing the maximum turbine output was determined to be $336 \mathrm{~kW}$ resulting in an average annual project output of $618,000 \mathrm{~kW}$ hours. The 
maximum turbine efficiency achieved averaged 79 percent. The turbine efficiency curve is shown in Figure 5.

\section{KEY PROJECT DATA}

Project name:

State:

Stream:

Project type:

Turbine type:

Number of units:

Installed capacity $(\mathrm{kW})$ :

Gross head (ft):

Total turbine flow (cfs):

Avg. annual estimated stream flow (cfs):

Avg. annual estimated energy ( $\mathrm{kWh})$ :

On-Line date:
Arbuckle Mountain Hydroelectric

California

Middle Fork of Cottonwood Creek

Low head

Cross-flow

1

336 (maximum)

55

10 to 106

43

618,000

December 1986

The turbine-generator and switchgear are shown in Photographs 1 and 2. The diversion structure is shown on the cover of this report.

\section{MAJOR REPAIRS}

Even though the project came on-line in December 1986, major field modifications to the turbine, nozzle, switchgear, and a complete rework of the generator only allowed periodic operation during the 1987 season. While in the field, the nozzle had to be rebuilt and the turbine reinforced to prevent the runner form grinding on the nozzle when the turbine was under load. To alleviate the problem, clearances between the nozzle and runner were increased to a point where considerable leakage occurs around the nozzle causing a nonstreamlined flow pattern and splash back against the runner. It was determined that building the turbinic out of thicker materials would allow tolerances to be tightened thus improving 
the efficiency of the unit. With improvements the turbine could reach efficiencies touted by the European manufactures of 85 percent and still be relatively inexpensive to manufacture. Even with the extensive modifications, the total cost of the turbine was only $\$ 304$ per kilowatt.

The original switchgear was installed to bring the generator on-line as an induction generator then switching over to synchronous operation. However, after a few trial starts, it was evident that the inrush currents to start the $450 \mathrm{hp}$ generator as induction were causing a drop in the utility system voltage and current. Therefore, the utility required the switchgear be changed over to start the generator as synchronous. This required extensive rewiring and delayed the generation by two months.

Extensive field testing revealed that the 1910 vintage generator had four out of the 40 poles shorted, five of the amortisseur windings of the poles burnt open, and because of past heat distortion the air gap between the rotor and stator varied as much as 0.200 of an inch. The poles were all rewound, the amortisseur windings repaired, and the centerline of the generator shaft adjusted so that the mean differences in the air gap averaged 0.015 of an inch. Four months were required to complete this work. Costs of these repairs and modifications were included as part of the original construction costs and were included in the "Final Construction and Cost Report". The turbine, generator and switchgear were ready to go back on-line in October 1987.

In early November 1987, while filling the pool, an operator error caused the powerhouse to be flooded. The operator had closed the radial gate at the dam to fill the pool. Because the low stream flow was filling the pool so slowly, he left the site. When he returned four days later, he found that a small one-inch penstock valve had been left open causing the lower floor of the powerhouse flooded to a depth of eight feet. Water and steam were pouring out of the side walls of the upper level. The steam was generated from the 2,400 volts heating the water because a fault relay did not function. Steam affected most of the electrical, switchgear, and computer components located on the upper floor. Many required extensive rehabilitation. On the lower floor the generator and all it components, the M-G set, and the 
compressor motor had to be dried out and rebuilt. All small motors, such as the slide gate motor, had to be replaced. All PT's and CT's had to be replaced and the switches rebuilt. Fortunately, insurance covered most of the $\$ 100,000$ worth of repairs. The repair work was complete and the plant was back on-line in January 1988.

During the first heavy flow in the creek each year, there is so much litter and debris that the air burst cleaning system can not completely clean the fish screens. As a result the screens require manual cleaning with a brush on a long pole after each "first flush" event. Previously, the operator attempted to do the cleaning from a small rubber boat which was dangerous and ineffective. Therefore, in June 1989 a new catwalk was installed over the fish screens that allows easy access to the screens in the event the screens require manual cleaning. The catwalk cost approximately $\$ 2,300$.

During operation in March several leaks developed in the PVC air line between the powerhouse and the fish screens at the diversion. The compressor in the powerhouse had to almost run constantly in order for the air pressure to remain sufficiently high to keep the screens clean. The compressor motor requires $5.6 \mathrm{~kW}$ or $135 \mathrm{~kW}$ hours per day to operate when running constantly. Ordinarily, it would require one sixth that amount. Since there have been problems before with the line, it was decided to replace it with 1,640 feet of 2-inch steel line at a cost of $\$ 2,540$. The work was completed in July 1989.

Once the above modifications were made to the turbine, generator, switchgear and air system the facility operates as planned. The sliding control gate that provides a continuous adjustment of flow to the turbine allows the turbine to operate down to six percent of full gate. With this feature the unit stays on line during periods of ra idly varying stream flow, thus optimizing the energy available from this flashy creek. 


\section{ANNUAL OPERATING EXPENSES}

The annual operating expenses are those that occur each year no matter what the operating conditions. Monthly summaries are shown for the three and half year period in Table 1 and explained in detail below.

Special Facility Charge is the monthly charge by the utility Pacific Gas and Electric (PG\&E) to cover the cost of special equipment that had to be added to their system before they would accept the power from the project. The equipment include suci facilities as reclosures, meters, and line upgrades. The charge is $\$ 140.55$ per month and runs the life of the 30-year power purchase contract.

Powerhouse Utility Bill is the monthly charge form PG\&E for power used in the powerhouse that exceeds the amount being generated by the plant. When the plant is generating and the outgoing power exceeds the needs of the powerhouse there is no charge. In nongenerating months the utility charge averages around $\$ 0.11$ per $\mathrm{kW}$ hour or around $\$ 130$ per month. The power usage is by the step up transformers, the generator warmers, the computer monitor, exhaust fan, lights, sump pumps, and compressor. In a nongenerating winter month the expense averages $\$ 250$ per month.

Telephone Charge includes the monthly connection charge plus any long distance charges. The monthly connection charge is $\$ 42$ and long distance charges average $\$ 15$ to $\$ 30$ per month. Since the plant is so remote all outgoing calls are long distance and mainly consists of the operator calling into the utility or the plant automatically calling the operator.

Fisheries Monitoring is required as part of the FERC License requirements. It consists of a fisheries biologist conducting an underwater inspection of the fish screens, ladder, and tailrace to ensure that all fish protection facilities are functioning. The surveys are conducted once per month from January through March and cost approximately $\$ 200$ each. 
FERC Charges are assessed to the project on an annual basis and currently runs $\$ 173$ per year.

Insurance consists of a $\$ 1$ millon liability policy and a fire insurance policy in case of forest fires. Other insurance is too costly for the project to support. These two insurances alone cost $\$ 2,350$ per year.

Plant Operator is on call continuously through out the generation season and is expected to visit the plant three times a week under normal operating conditions. During the season the operator is paid $\$ 400$ per month.

Accounting fees for the annual income tax preparation for the project partnership averages around $\$ 1,300$.

County Taxes for the project took three years to negotiate. The final annual taxes were settled at $\$ 1,676$.

Miscellaneous Expenses such as records, bank charges, etc., average around $\$ 300$ per year.

Annual Maintenance includes a complete inspection of all components of the plant, maintenance of all equipment, cleaning, and repair or replacement of any worn or damaged components. This maintenance labor and parts averages around $\$ 3,800$.

The large maintenance charge for the month of May 1990 included the cost of annual maintenance $(\$ 3,000)$, new walk bridge to the operators cabin $(\$ 2,500)$, replacement of the air line $(\$ 2,540)$, new cat walk above the screens $(\$ 2,300)$, and repair of insulators damaged by hunters $(\$ 717)$. 
As shown above and in Table 1, the annual operation and maintenance cost of the plant averages around $\$ 17,000$.

\section{EFFECTS OF LOW WATER YEARS}

In the northern California area where this project is located, the annual rainfall for the last four years has ranged 60 to 80 percent of normal resulting in stream flows as low as 28 percent of normal. When large storms did come, they occurred in intense rainfall events resulting in short high runoff events, thus exceeding the capacity of small run-of-river projects such as this. Most of the small run-of-river hydro projects in this area generated only about 20 to 35 percent of their forecasted energy.

The Cottonwood Creek watershed in which this project is located is best characterized by the USGS stream gage on the main stem of Cottonwood Creek Near Cottonwood, California (Gage No. 11376000). The stream gage measures the total runoff of the basin and has an excellent record since 1940. The average annual streamflow for this 50 -year period is 857 cfs. Listed below are recorded stream flows for the last four years.

\begin{tabular}{ccc} 
Year & Flow (cfs) & \% of Normal \\
\cline { 2 - 3 } 1987 & 298 & 34.8 \\
1988 & 440 & 51.3 \\
1989 & 481 & 56.1 \\
1990 & 244 & 28.5
\end{tabular}

In the 1989 season, 35 to 45 percent of the annual precipitation and runoff occurred in the month of March, causing high stream flows the small run-of-river plant could not effectively utilize.

The 1990 season was the driest of the four years. One small storm occurred in mid-January, but the only storm of any significance occurred at the end of May, which resulted in over 60 percent of the generation for that year. 
Another measure of long-term water conditions in the watershed above the project is reflected by the rain gage located at the approximate centroid of the watershed at the Harrison Gulch Ranger station. This daily recording rain gage has a 36-year average annual precipitation of 36.56 inches. Listed below are the recorded annual amounts for the last three years.

$\begin{array}{lcc}\text { Year } & \text { Precipitation (inches) } & \text { \% of Normal } \\ 1987 & 24.03 & 65.7 \\ 1988 & 27.22 & 74.5 \\ 1989 & 30.14 & 82.4 \\ 1990 & 25.23 & 69.0\end{array}$

Because of these drought conditions and the storms that did occur being of the high-intense short-duration type that produced flashy events, the production of the project has been only a small fraction of that expected from the unit. Short-term high flows are shown in Photographs 3 and 4 . The foreca:ted and actual stream flow and production are shown in is shown in Table 2.

To date, the maximum monthly generations occurred in January 1988 and March 1989. Eoth averaged around $108 \mathrm{~kW}$ for the month, with a peak day average of $313 \mathrm{~kW}$ at the utility meter. 


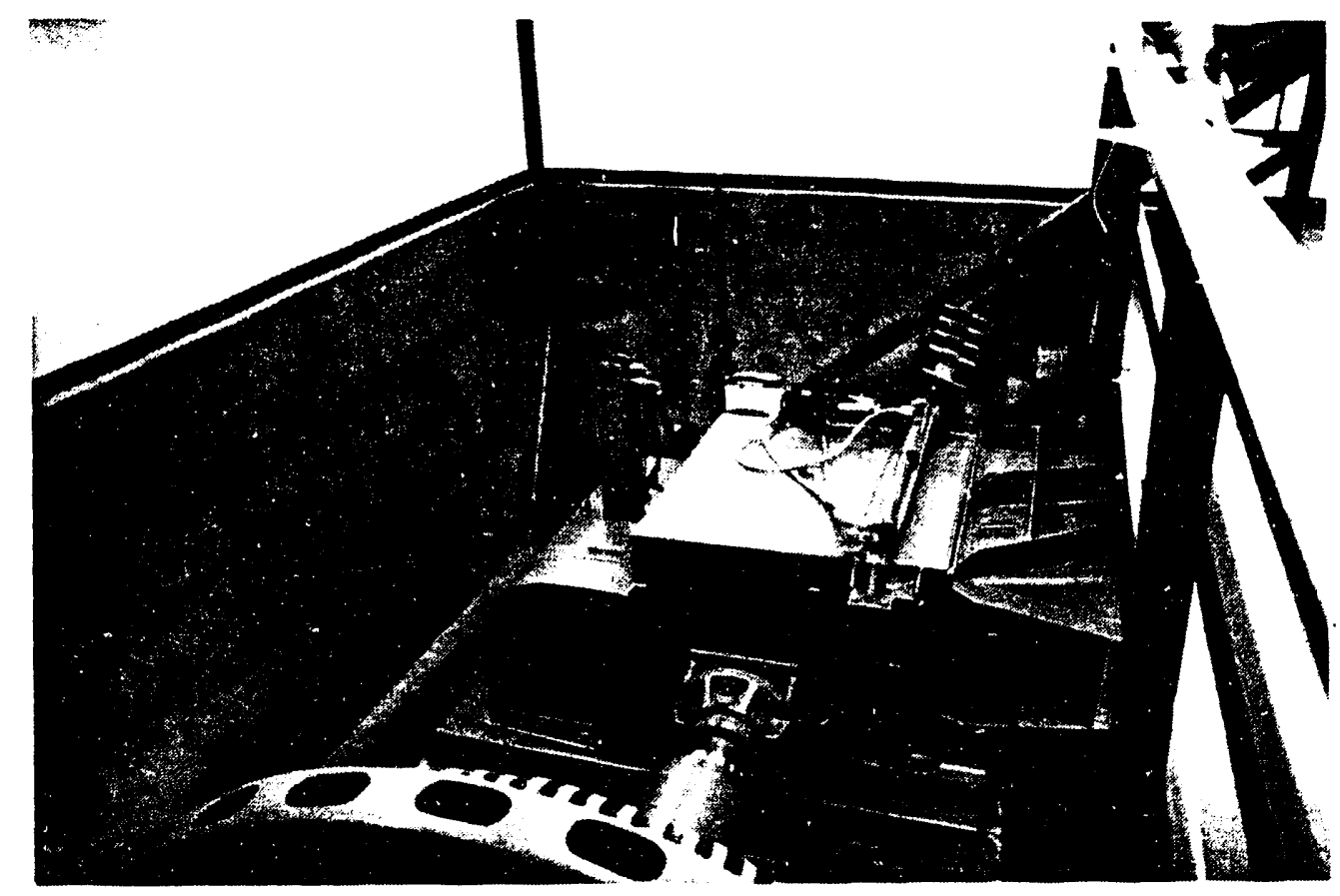

PHOTOGRAPH 2. GENERATOR - SWITCHGEAR

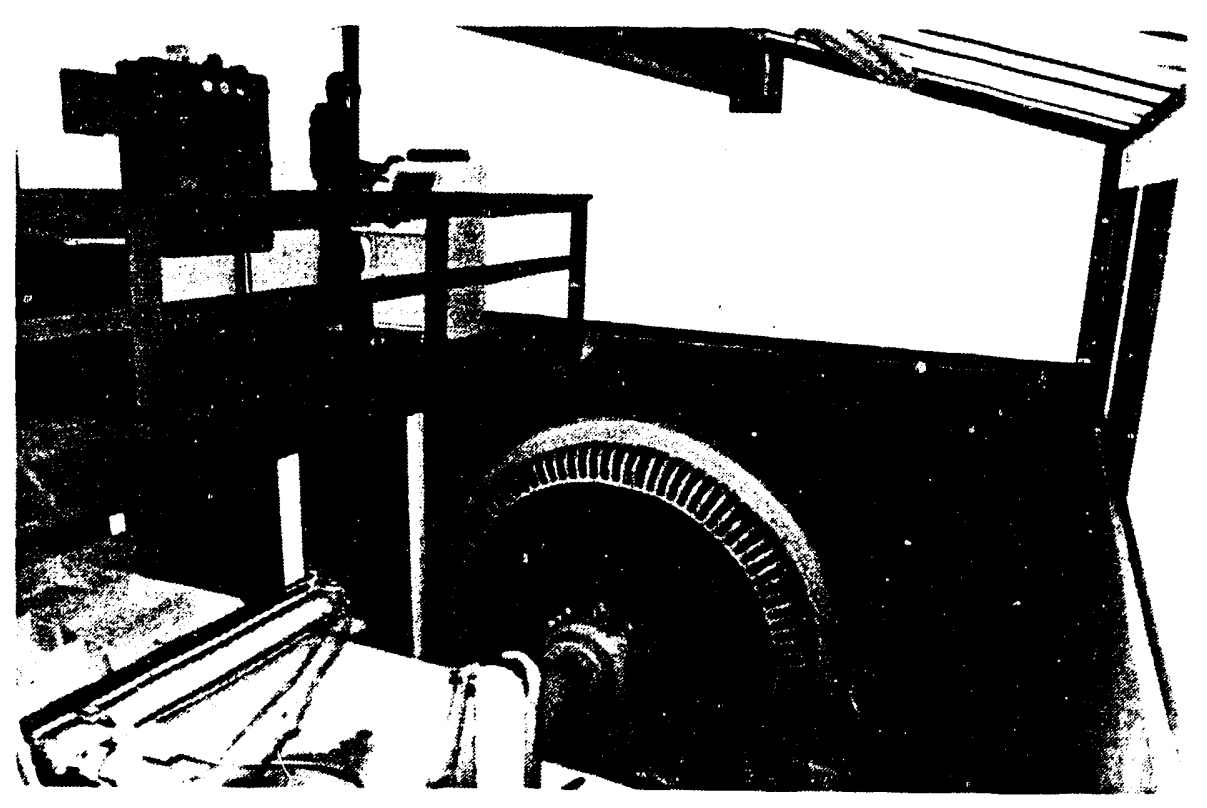




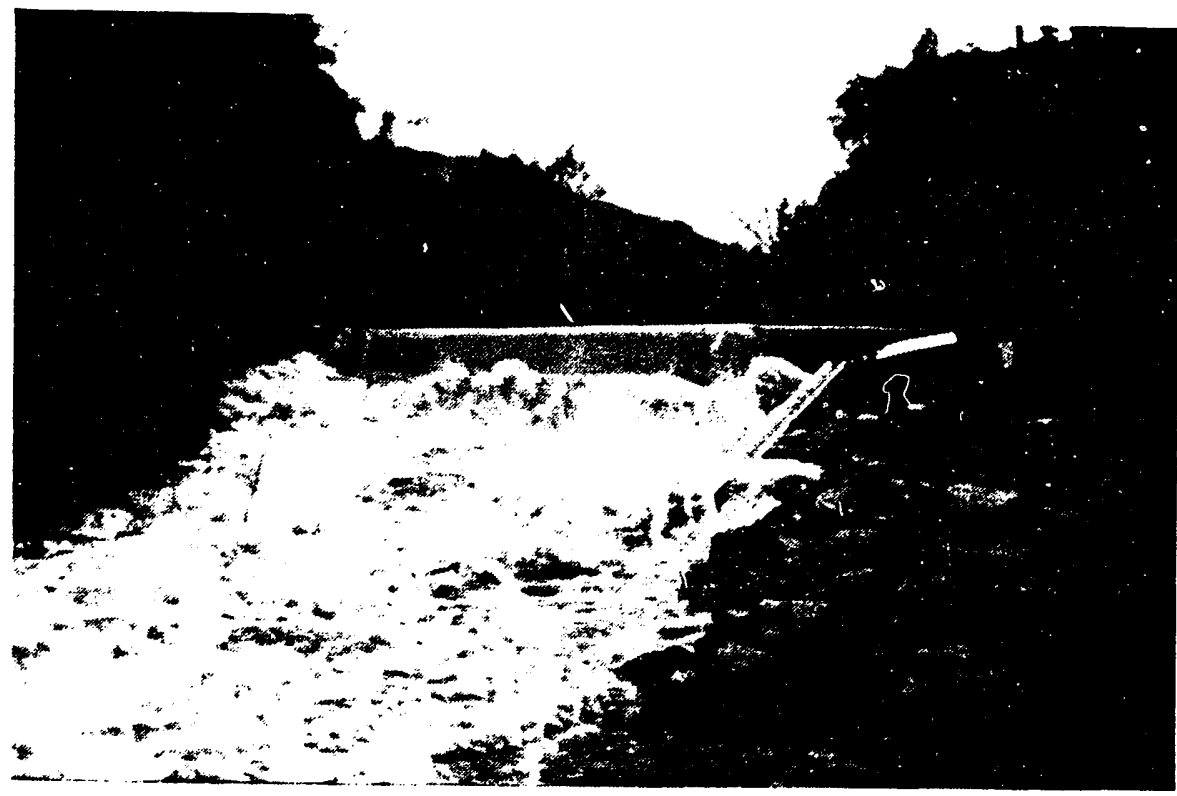

PHOTOGRAPH 4.

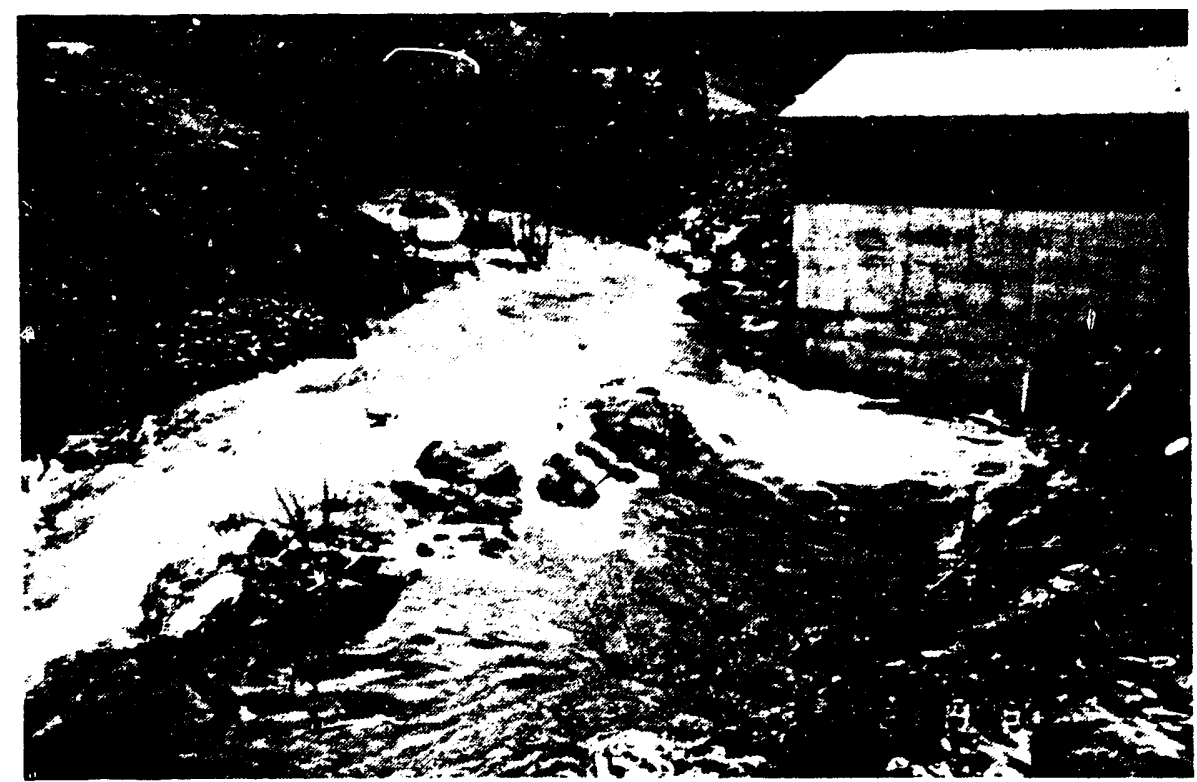


TABLE 1

OPERATION AND MAINTENANCE COST

Jan 87

Feb 87

Mar 87

Apr 87

May 87

Jun 87

Jul 87

Aug 87

Sep 87

Season

Oct 87

Nov 87

Dec 87

Jan 88

Feb 88

Mar 88

Apr 88

May 88

Jun 88

Jul 88

Aug 88

Sep 88

Season

Oct 88

Nov 88

Dec 88

Jan 89

Feb 89

Mar 89

Apr 89

May 89

Jun 89

Jul 89

Aug 89

Sep 89

Season

\section{Operating \\ Cost}

$\$ 446$

813

996

934

848

822

1,058

558

555

7,030

269

886

831

1,300

2,102

1,228

2,856

1,313

531

404

480

269

12,469

436

449

1,635

424

1,274

578

556

1,714

526

510

718

1,989

10,809
Maintenance

Cost

$\$ 261$

0

611

1,405

24

1,008

0

49

912

4,270

0

1,807

0

0

0

0

0

0

3,665

0

0

0

5,472

714

0

1,243

196

0

100

992

399

0

0

2,539

0

6,183
Total

Cost

$\$ 707$

813

1,607

2,339

872

1,830

1,058

607

1,467

11,300

269

2,693

831

1,300

2,102

1,228

2,856

1,313

4,196

404

480

269

17,941

1,150

449

2,878

620

1,274

678

1,548

2,113

526

510

3,257

1,989

16,992 
TABLE 1 (Continued)

\begin{tabular}{|c|c|c|c|}
\hline & $\begin{array}{c}\text { Operating } \\
\text { Cost } \\
\end{array}$ & $\begin{array}{c}\text { Maintenance } \\
\text { Cost } \\
\end{array}$ & $\begin{array}{l}\text { Total } \\
\text { Cost }\end{array}$ \\
\hline Oct 89 & 408 & 625 & $\$ 1,033$ \\
\hline Nov 89 & 246 & 0 & 246 \\
\hline Dec 89 & 2,671 & 1,253 & 3,924 \\
\hline $\operatorname{Jan} 90$ & 585 & 36 & 621 \\
\hline Feb 90 & 805 & 0 & 805 \\
\hline Mar 90 & 1,290 & 249 & 1,539 \\
\hline Apr 90 & 3,364 & 0 & 3,364 \\
\hline May 90 & 427 & 11,057 & 11,484 \\
\hline Jun 90 & 141 & 0 & 141 \\
\hline Jul 90 & 419 & 175 & 594 \\
\hline Aug 90 & 210 & 0 & 210 \\
\hline Sep 90 & 2,347 & 0 & 2,347 \\
\hline Season & 12,913 & 13,395 & 26,308 \\
\hline
\end{tabular}


TABLE 2

STREAM FLOW AND PRODUCTION

Historical

Stream

Flow (cfs)

Jan 87

Feb 87

Mar 87

Apr 87

May 87

Jun 87

Jul 87

Aug 87

Sep 87

Season

Oct 87

Nov 87

Dec 87

Jan 88

Feb 88

Mar 88

Apr 88

May 88

Jun 88

Jul 88

Aug 88

Sep 88

Season

Oct 88

Nov 88

Dec 88

Jan 89

Feb 89

Mar 89

Apr 89

May 89

Jun 89

Jul 89

Aug 89

Sep 89

Season
102

122

105

72

27

10

4

1

1

43

5

23

45

102

122

105

72

27

10

4

1

1

43

5

23

45

102

122

105

72

27

10

4

1

1

43
Actual

Stream

Flow (cfs)

16

52

84

27

9

3

1

0

0

19

0

0

60

111

32

15

10

5

1

0

0

0

20

0

30

15

36

20

162

45

15

5

1

0

0

27
Forecasted

Production

(kWh)

88,000

115,000

128,000

98,000

55,000

9,000

0

0

0

493,000

3,000

42,000

80,000

88,000

115,000

128,000

98,000

55,000

9,000

0

0

0

618,000

3,000

42,000

80,000

88,000

115,000

128,000

98,000

55,000

9,000

0

0

0

618,000
Actual

Production

(kWh)

3,960

18,180

46,260

180

0

0

0

0

68,580

0

0

78,119

5,749

1,452

1,452

0

0

0

0

0

85,320

0

5,580

16,560

18,753

332

75,452

17,388

2,556

0

0

0

0

136,621
Production

Value

(\$)

238

1,143

2,893

13

0

0

0

0

0

4,287

0

0

0

5,272

388

0

98

0

0

0

0

0

5,758

378

1,160

1,406

26

5,654

1,302

192

0

0

0

0

10,118 
TABLE 2 (Continued)

\begin{tabular}{|c|c|c|c|c|}
\hline $\begin{array}{r}\text { Historical } \\
\text { Stream } \\
\text { Flow (cfs) } \\
\end{array}$ & $\begin{array}{c}\text { Actual } \\
\text { Stream } \\
\text { Flow (cfs) } \\
\end{array}$ & $\begin{array}{c}\text { Forecasted } \\
\text { Production } \\
(\mathrm{kWh}) \\
\end{array}$ & $\begin{array}{c}\text { Actual } \\
\text { Production } \\
(\mathbf{k W h}) \\
\end{array}$ & $\begin{array}{c}\text { Production } \\
\text { Value } \\
(\$) \\
\end{array}$ \\
\hline 5 & 7 & 3,000 & 649 & 36 \\
\hline 23 & 11 & 42,000 & 171 & 28 \\
\hline 45 & 9 & 80,000 & 203 & 231 \\
\hline 102 & 52 & 88,000 & 8,713 & 453 \\
\hline 122 & 30 & 115,000 & 147 & 14 \\
\hline 105 & 21 & 128,000 & 21 & 0 \\
\hline 72 & 7 & 98,000 & 0 & 15 \\
\hline 27 & 10 & 55,000 & 13,175 & 1,727 \\
\hline 10 & 10 & 9,000 & 5,061 & 0 \\
\hline 4 & 2 & 0 & 0 & 0 \\
\hline 1 & 0 & 0 & 0 & i) \\
\hline 1 & 0 & 0 & 0 & $J$ \\
\hline --.-. & --.--- & -......... & --.--..- & .......... \\
\hline 43 & 13 & 618,000 & 28,140 & 2,504 \\
\hline
\end{tabular}

Oct 89

Nov 89

Dec 89

Jan 90

Feb 90

Mar 90

Apr 90

May 90

Jun 90

Jul 90

Aug 90

Sep 90

Season

\section{Historical \\ Stream}

Actual
Stream
Flow (cfs)

13
Forecasted

(kWh)

618,000 


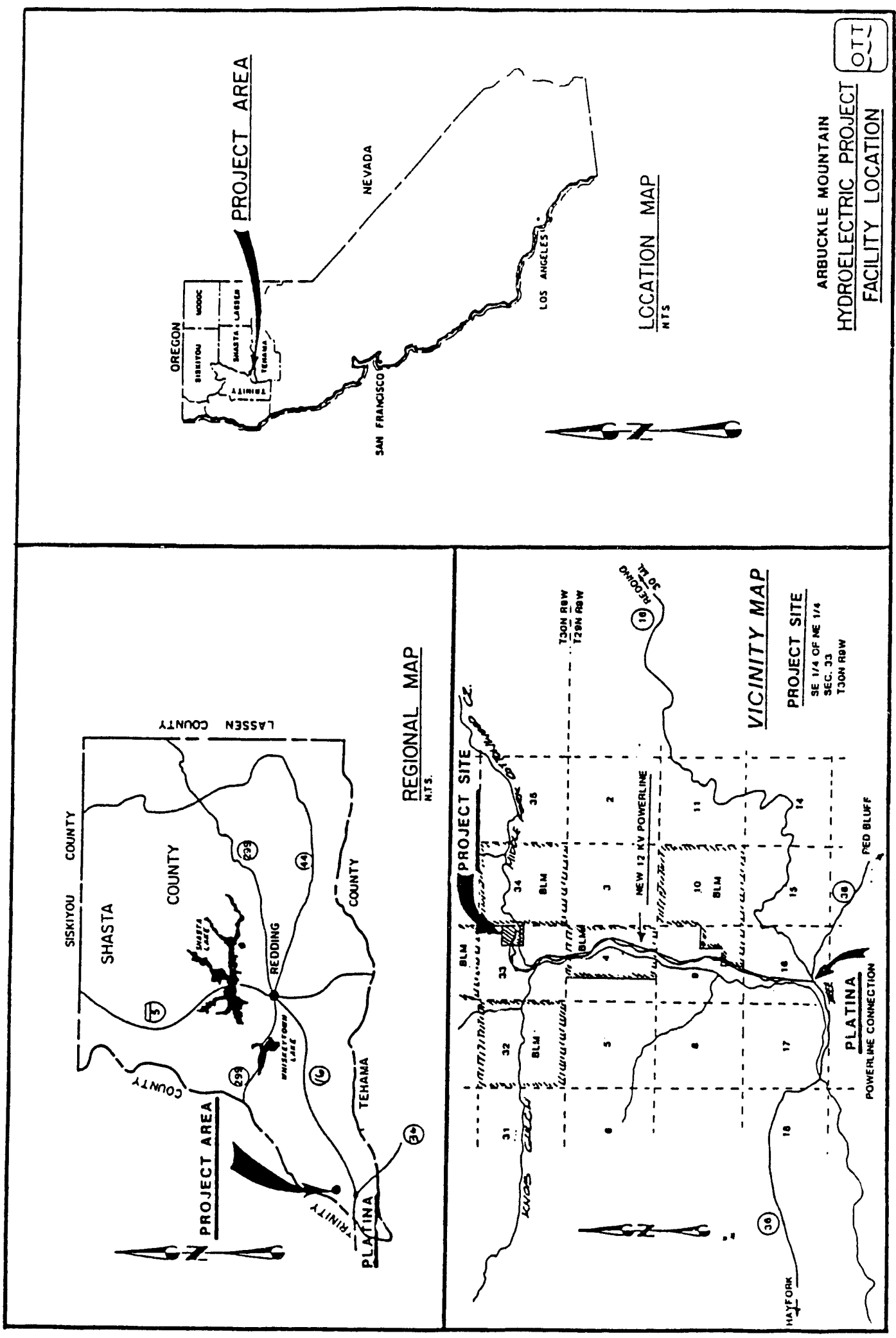

2
$\frac{2}{6}$
8
$\frac{1}{0}$
$\frac{1}{4}$

$\frac{\dot{1}}{4}$ 


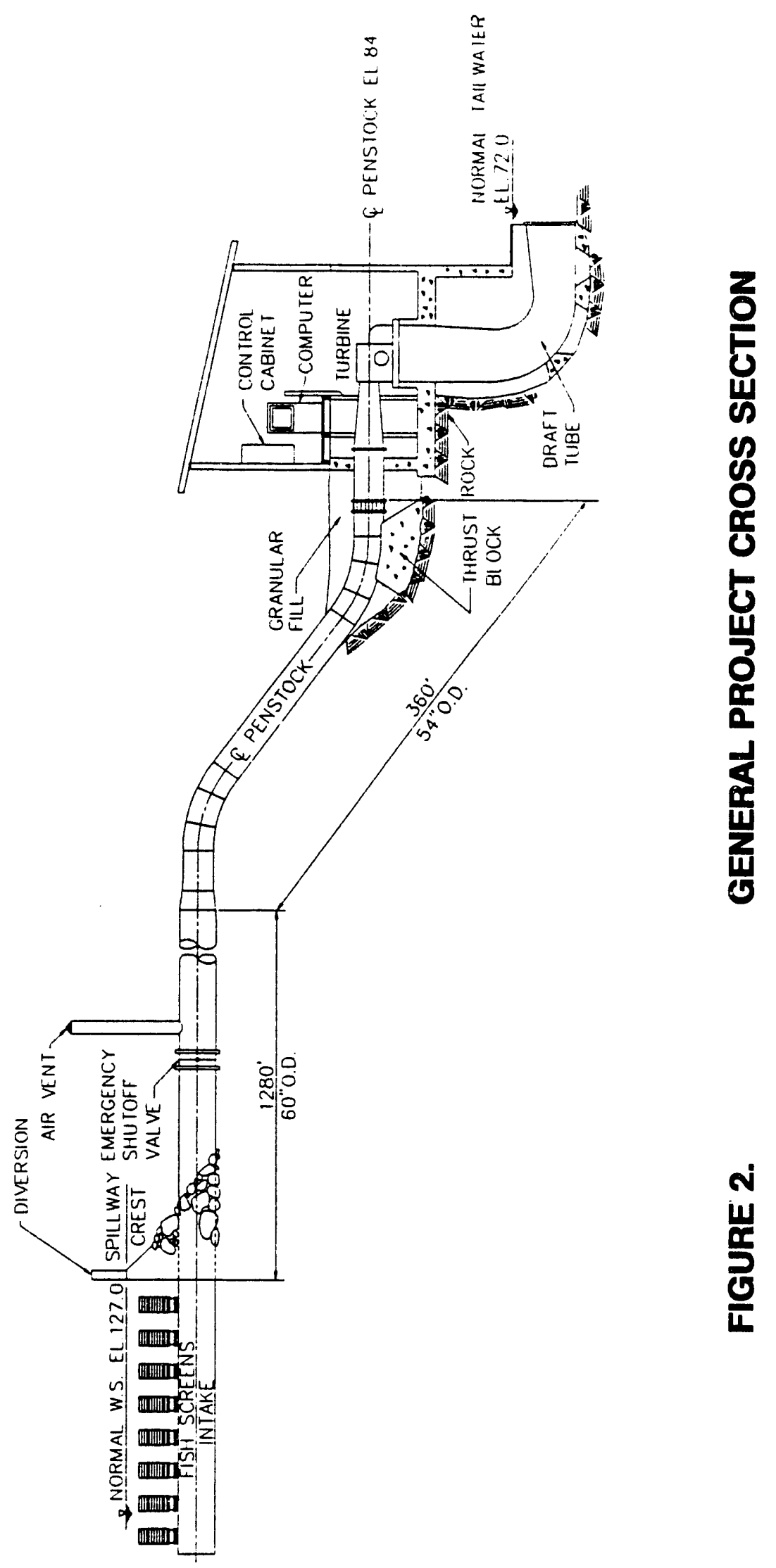




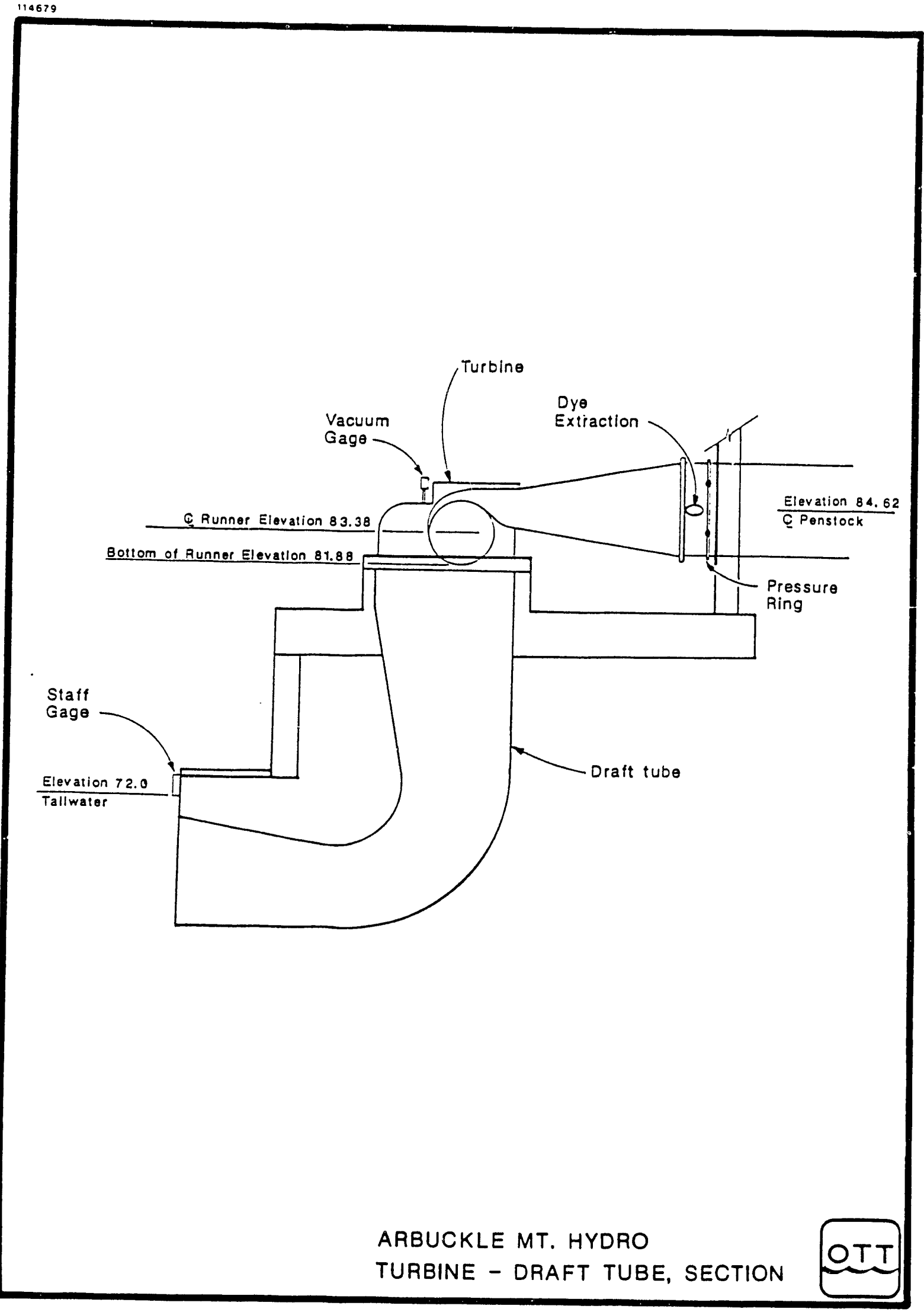

FIGURE 3. 


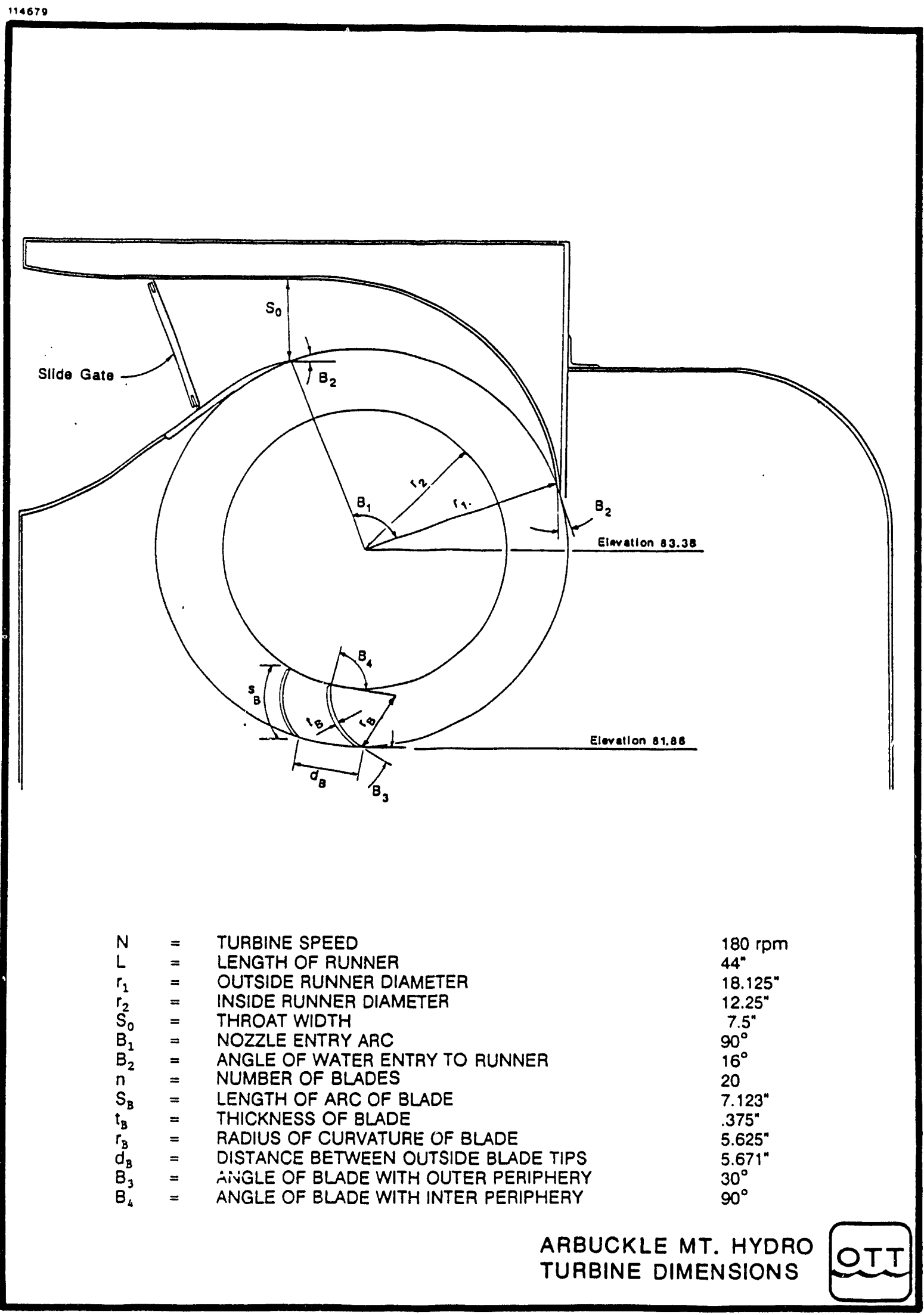

FIGURE 4. 


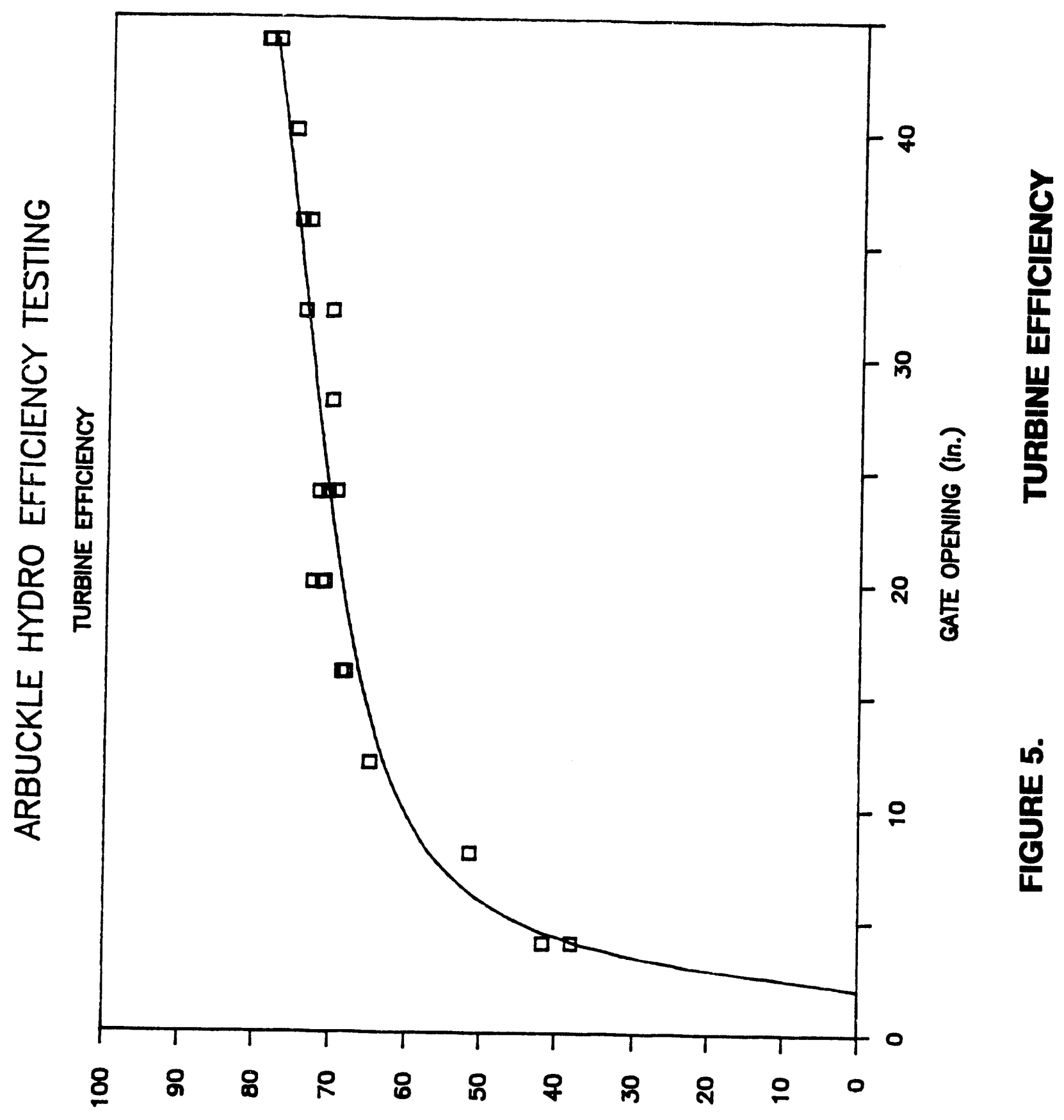

(6) LONGIOLA]I INIEYRL 

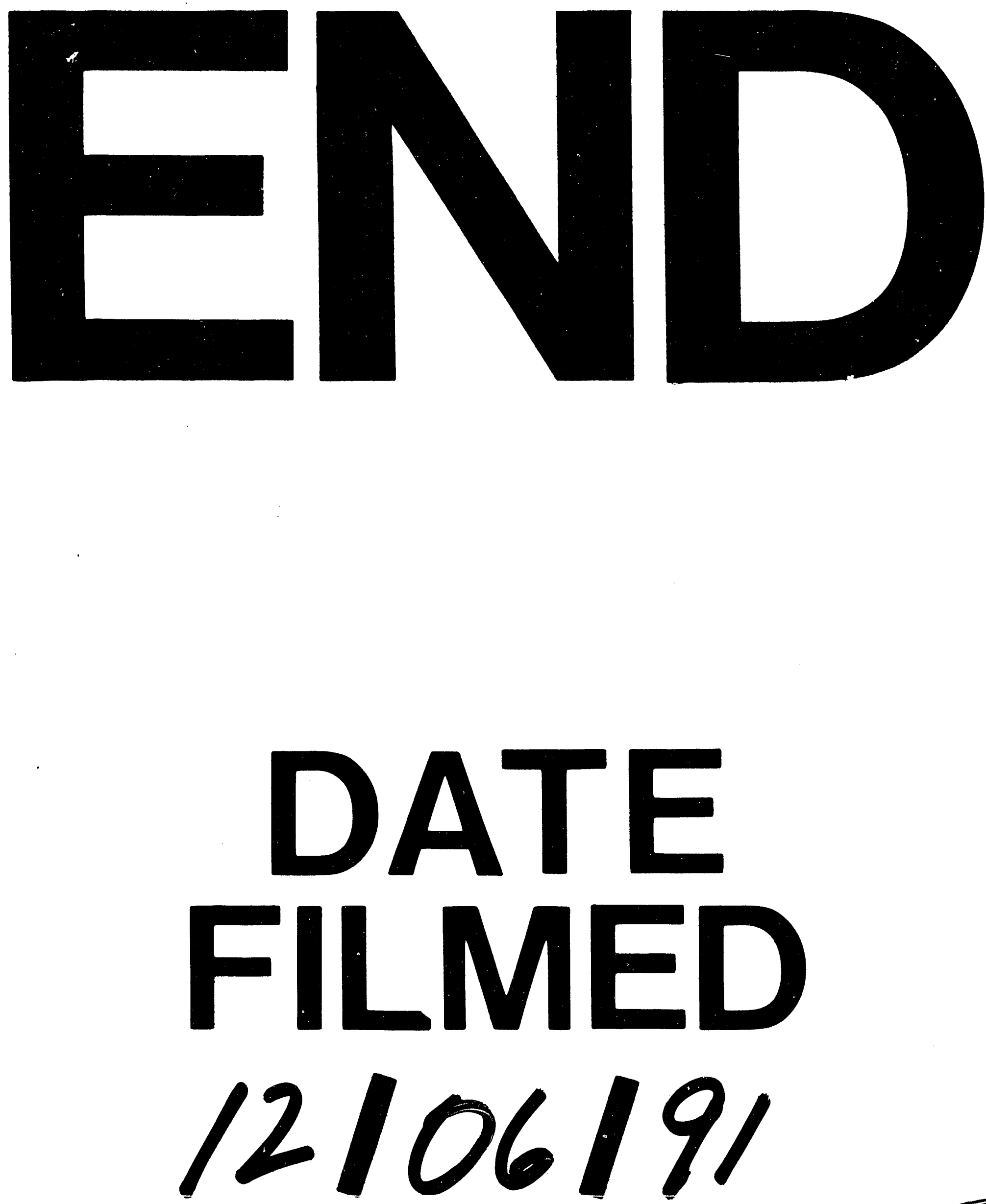

I 
